\title{
Pemberian Scaffolding untuk Mengatasi Kesalahan Siswa Dalam Menyelesaikan Masalah Matematika
}

\author{
AYU ISMI HANIFAH \\ Universitas Islam Lamongan \\ ayuismihanifah@gmail.com
}

\begin{abstract}
:
Untuk mengembangkan cara berpikir dalam pembelajaran matematika perlu adanya pemberian masalah matematika. Adanya masalah matematika dapat menyelesaikan masalah karena dengan dengan penyelesaian masalah merupakan bagian dari pembelajaran matematika. Pemberian masalah matematika ini digunakan guna mengukur kemampuan siswa dalam menguasai materi yang telah dipelajari. Tidak memungkinkan adanya siswa mengalami kesalahan ketika menyelesaikan masalah bahkan ketika siswa memahami suatu konsep matematika. Salah satu cara yang mungkin untuk mengatasi kesalahan siswa yaitu dengan memberikan scaffolding. Tujuan dari penelitian ini yaitu untuk mendeskripsikan scaffolding yang diberikan untuk mengatasi kesalahan siswa dalam menyelesaikan masalah matematika. Jenis penelitian ini termasuk penelitian deskriptif dengan pendekatan kualitatif. Sumber data dalam penelitian ini berupa data tertulis, kata-kata, dan hasil dokumentasi. Hasil penelitian ini menunjukkan bahwa pemberian scaffolding untuk mengatasi kesalahan siswa dalam menyelesaikan masalah matematika yaitu 1) Scaffolding dalam penyusunan model matematika dalam bentuk aljabar; 2) Scaffolding dalam membangun kembali konsep bangun datar, khususnya luas dan keliling persegi dan persegi panjang; 3) Scaffolding dalam menyelesaikan operasi bentuk aljabar; dan 4) Scaffolding dalam memanfaatkan teorema Pythagoras dalam menyelesaikan masalah matematika.
\end{abstract}

Kata Kunci: scaffolding, kesalahan, masalah matematika

\section{Pendahuluan}

Matematika memiliki peranan penting dalam berbagai aspek kehidupan. Menurut Hudojo (2003) "matematika merupakan suatu alat untuk mengembangkan cara berpikir". Untuk mengembangkan cara berpikir dalam pembelajaran matematika perlu adanya pemberian masalah matematika. Adanya masalah matematika dapat menyelesaikan masalah karena dengan dengan penyelesaian masalah merupakan bagian dari pembelajaran 
matematika. Adanya penerapan penye-lesaian masalah pada proses pembelajaran dapat meningkatkan cara berpikir siswa, membangkitkan rasa ingin tahu, dan dapat memahami suatu permasalahan dengan baik (NCTM, 2000:52). Pemberian masalah matema-tika ini digunakan guna mengukur kemam-puan siswa dalam menguasai materi yang telah dipelajari. Tidak memungkinkan adanya siswa meng-alami kesalahan ketika menyelesaikan masalah bahkan ketika siswa mema-hami suatu konsep matematika.

Salah satu cara yang mungkin untuk mengatasi kesalahan siswa yaitu dengan memberikan scaffolding. Scaffolding ini merupakan metode yang didasari pada teori Vygotsky. Menurut Vygotsky (dalam Trianto, 2010: 76) bahwa pembelajaran terjadi apabila anak bekerja atau belajar menangani tugas-tugas yang belum dipelajari namun tugas-tugas itu masih berada dalam jangkauan kemampuannya atau tugas-tugas tersebut berada dalam Zone of Proximal Development (ZPD) yaitu perkembangan sedikit di atas perkembangan seseorang saat ini. Penelitian tentang scaffolding telah banyak dilakukan diantaranya Pol dan Ed (2013), Howe (2013), Bikmaz (2010), Amiripour, dkk (2012). Salah satu pemberian scaffolding juga dilakukan oleh Crespo (2003) dan Speer (2009) dalam penelitiannya dengan melakukan diskusi dengan siswa. Anghileri (2006) dalam penelitiannya mengemukakan bahwa terdapat tiga level scaffolding yaitu
Scaffolding level 1 (environmental provisions), Scaffolding level 2 (explaining, reviewing, and restructuring), dan Scaffolding level 3 (developing conceptual thinking).

Pada penelitian ini, scaffolding diberikan kepada siswa yang masih mengalami kesalahan dalam menyelesai-kan masalah matematika. Penyelesaian masalah matematika diambil dari jurnal analisis kesalahan siswa yang ditulis oleh Hanifah (2017). Dari hasil penyelesaian masalah tersebut, penelitian kali ini dilakukan dalam mengatasi kesalahan yang terjadi dengan memberikan scaffolding. Scaffolding dilakukan dengan melakukan diskusi langsung bersama siswa terhadap hasil penyelesaian masalah yang diberikan. Dengan pemberian scaffolding ini diharapkan siswa dapat menyelesaikan masalah matematika dengan tepat.

Penelitian ini merupakan penelitian hasil uji coba. Rumusan masalah dalam penelitian ini adalah pemberian scaffolding untuk mengatasi kesalahan siswa dalam menyelesaikan masalah matematika. Tujuan dari penelitian ini yaitu untuk mendeskripsikan scaffolding yang diberikan untuk mengatasi kesalahan siswa dalam menyelesaikan masalah matematika. Scaffolding diberikan melalui wawancara langsung bersama siswa terhadap hasil penyelesai-an masalah matematika. Masalah matematika dalam penelitian ini yaitu masalah yang mencakup tentang aljabar, diantaranya yaitu operasi 
aljabar, luas dan keliling bangun datar. Dengan adanya penelitian ini diharapkan dapat membantu guru langkah pemberian scaffolding ketika siswa mengalami kesalahan agar siswa tidak mengalami kesalahan lagi dan dapat menyelesaikan masalah matematika sesuai penyelesaian yang diharapkan.

\section{Metode Penelitian}

Penelitian ini termasuk penelitian deskriptif dengan pendekatan kualitatif, sesuai dengan tujuan penelitian yang telah dipaparkan. Penelitian kualitatif merupakan penelitian yang ditujukan untuk mendeskripsikan dan menganalisis fenomena, peristiwa, aktivitas sosial, sikap, kepercayaan, persepsi, pemikiran orang secara individual maupun kelompok (Sukmadinata, 2009:60). Penelitian deskriptif menggambarkan apa adanya terkait tentang sesuatu variabel, gejala atau keadaan (Arikunto, 2010:21). Subjek yang dipilih adalah siswa kelas 8 yang telah menempuh materi aljabar, luas dan keliling bangun datar. Selain itu, subjek yang dipilih yaitu subjek yang mengalami kesalahan dalam menyelesaikan masalah yang diberikan dan mampu berkomunikasi agar pengungkapan proses berpikir dapat dilakukan dengan baik.

Sumber data dalam penelitian ini berupa data tertulis, kata-kata, dan hasil dokumentasi. Untuk prosedur pengum-pulan data, sumber data tertulis diperoleh dari hasil penyelesaian masalah oleh siswa. Sumber data berupa kata-kata diperoleh ketika wawancara dilakukan ketika scaffolding diberikan. Sedangkan sumber data dokumentasi diperoleh dari rekaman suara ketika proses wawancara dilakukan ketika scaffolding diberikan. Prosedur penelitian yang digunakan dalam penelitian ini diantaranya yaitu melakukan kegiatan pendahuluan, menyusun masalah matematika, membuat skema struktur masalah dari masalah yang telah dibuat, diskusi dengan teman sejawat, mengumpulkan data, menganalisis data, serta menarik kesimpulan. Analisis data dilakukan menurut Creswell (2012: 261-262) dengan langkah-langkah: 1) menyiapkan dan mengelola data, 2) memeriksa dan menandai data, 3) pengkodean data untuk mendeskripsi-kan tema temuan, (4) menyajikan dan melaporkan temuan, (5) menafsirkan temuan, dan (6) pengecekan keabsahan temuan. Data yang dikumpul-kan adalah lembar hasil jawaban siswa dalam menyelesaikan masalah matematika yang mengalami kesalah-an. Kesalahan yang terjadi yaitu kesalahan siswa dimana siswa belum dapat memunculkan skema yang seharusnya dimunculkan dalam menyelesaikan masalah yang diberikan.

Dalam menyelesaikan masalah yang diberikan, siswa diminta untuk menulis-kan jawaban penyelesaian secara rinci, tepat dan jelas. Masalah matematika dan jawaban masalah matematika yang digunakan telah 
didiskusikan dengan teman sejawat terlebih dahulu. Berdasar-kan jawaban masalah matematika tersebut, peneliti dapat menentukan letak kesalahan siswa sehingga peneliti dapat melakukan pemberian scaffolding khususnya pada letak kesalahan siswa ketika menyelesaikan masalah matematika.

\section{Hasil dan Pembahasan}

Dalam penelitian ini, kesalahan siswa ditemukan ketika menyelesaikan masalah dalam materi aljabar diantaranya mencakup materi operasi aljabar, luas dan keliling bangun datar. Selanjutnya, peneliti membuat rancangan wawancara yang akan dilakukan ketika pemberian scaffolding dilakukan. Scaffolding ini berkaitan khususnya pada letak kesalahan siswa dalam menyelesaikan masalah matematika. Dari hasil penyelesaian masalah matematika yang mengalami kesalahan, peneliti menetapkan tiga subjek yang memenuhi kriteria subjek penelitian. Berikut pemaparan kesalahan struktur berpikir Subjek 1 (S1) dan Subjek 2 (S2) berdasarkan masalah matematika yang diberikan.

\section{Masalah Matematika Nomor 1}

Dari permasalahan panjang suatu persegi panjang $2 \mathrm{~cm}$ lebih dari dua kali lebarnya. Keliling persegi panjang tersebut sama dengan keliling suatu persegi yang luasnya 256 cm2. Tentukanlah ukuran persegi panjang tersebut!. S1 mengalami kesalahan ketika mencari panjang persegi panjang yang ditanyakan. Hal ini berkaitan dengan pemahaman siswa ketika menuliskan informasi yang diketahui dalam per-masalahan. Dari kesalahan tersebut mengakibatkan kurang tepatnya langkah sampai jawaban yang dihasilkan.

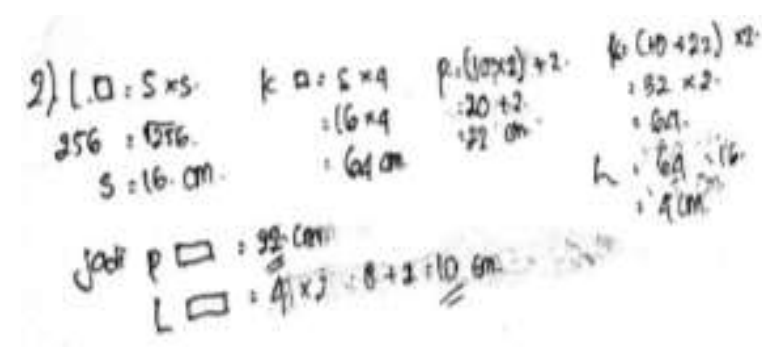

Gambar 1: Jawaban S1 dalam Menyelesaikan Masalah Nomor 1

Oleh karena itu, peneliti memberikan scaffolding dengan melakukan tanya jawab terhadap S1 seperti berikut.

Peneliti : Coba perhatikan, panjang kebun $5 m$ kurangnya dari tiga kali lebar kebun! Maksud dari kalimat tersebut bagaimana?

Subjek 1: tiga kalinya lebar terus dikurangi sama 5

Peneliti : Berarti panjang samadengan? Sebelumnya, kamu memisalkan lebar dengan apa?

Subjek 1: Dimisalkan bagaimana?

Peneliti : Misal lebar kamu misalkan dengan variabel apa gitu?

Subjek 1: Misal lebar saya misalkan l boleh?

Peneliti : Boleh, terserah kamu memakai variabel apa. Kemudian kalau panjangnya? 
Subjek 1: Panjang=p, $p=5 m$ kurangnya dari $3 \times$ lebar

Peneliti : Lebar tadi kamu misalkan l, jadi panjangnya?

Subjek 1: Ini kan 3×lebar berarti 31 kemudian dikurangi 5 jadi panjangnya, $p=3 l-5$

Dengan adanya scaffolding tersebut, S1 dapat memahami informasi yang diketahui maupun yang ditanyakan dengan tepat sehingga ketika melanjut-kan penyelesaian soal nomor 1, S1 tidak mengalami kesulitan dan memperoleh jawaban dengan tepat.

Pada penyelesaian masalah nomor 1, kesalahan yang dilakukan S2 mirip halnya dengan S1. Kesalahan awal dilakukan yaitu ketika S2 memahami informasi permasalahan. S2 tidak dapat memahami dengan benar sehingga tidak dapat menuliskan informasi yang diketahui dengan tepat.

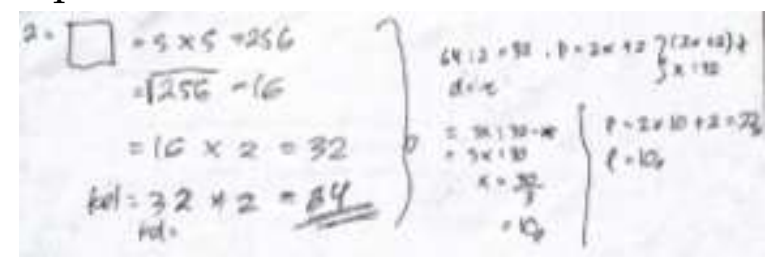

Gambar 2: Jawaban S2 dalam Menyelesaikan Masalah Nomor 1

Berikut scaffolding yang diberikan peneliti kepada S2 sehingga S2 tidak mengalami kesalahan dalam menuliskan informasi yang diketahui.

Peneliti : Lihat ini dulu, tadi kan dimisalkan lebarnya $x$, kalau panjangnya $5 m$ kurangnya dari lebar itu bagaimana?
Subjek 2: $x-5$

Peneliti : Nah, sekarang kalau panjangnya $5 m$ kurangnya dari $3 \times$ lebar, berarti bagaimana?

Subjek 2: $3 x-5$

Peneliti : Kalau digambar yang tadi, 3x-5 sebelah mana?

Subjek 2: Yang ini (menunjuk panjang kebun)

Peneliti : Sekarang, luas jalan pinggir kebun $12 m^{2}$ itu yang mana?

Subjek 2: Yang yang ini, yang gak diarsir

Peneliti : Kebunnya itu berbentuk apa?

Subjek 2: Persegi panjang

Peneliti : Untuk nyaris luasnya bagaimana?

Subjek 2: Panjang kali lebar

Dengan adanya pemberian scaffolding ini, S2 dapat mengilustrasikan bentuk bangun datar yang diinformasi-kan pada soal sehingga S2 dapat memahami maksud informasi dengan jelas dan dapat menuliskan informasi yang diketahui dengan tepat. Selanjut-nya, S2 sempat mengalami kebingungan ketika mengoperasikan bentuk aljabar. Namun, dengan diberikannya scaffolding, S2 akhirnya dapat menyelesaikan masalah nomor 1 dengan tepat. Selain itu, S2 dapat menjelaskannya dengan rinci langkahlangkah jawaban yang telah diperoleh.

\section{Masalah Matematika Nomor 2}

Masalah matematika nomor 2 yaitu Diketahui dua persegi panjang $A$ dan B. Luas persegi panjang $A$ adalah $3 / 2$ kali luas persegi panjang B. Panjang bangun A sama dengan panjang bangun 
B. Kuadrat panjang diagonal bangun $B$ adalah $13 x^{2}+32 x+20$ dan panjang bangun $B$ adalah $3 x+4$. Tentukan kuadrat panjang diagonal A! (Gambarkan persegi panjang yang ada pada permasalahan). Dari masalah matematika nomor 2, S1 meng-alami kesalahan ketika memodelkan matematika dari yang diketahui, untuk langkah penyelesaian sebenarnya sudah benar namun, ketika menyelesaikan langkah menggunakan model matema-tika tersebut S2 kebingungan sehingga mendapatkan hasil jawaban dengan cara mencobacoba.

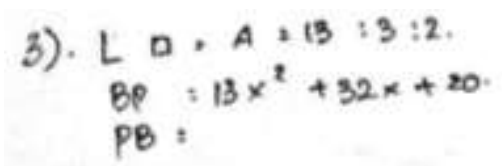

Gambar 3: Jawaban S1 dalam Menyelesaikan Masalah Nomor 2

Berikut scaffolding yang diberikan peneliti kepada S1 sehingga S1 tidak mengalami kesalahan dalam menuliskan model matematika.

Peneliti: Luas bangun A 3:2 dengan luas bangun B? Coba dibaca lagi soalnya.

Subjek 1: Iya, Bu. Ini kan 3/2 diketahuinya.

Peneliti : 3/2 kali. Seperti nomor 1 dan nomor 2 tadi. Itu kan luas A dan luas B sudah kamu misalkan, kemudian ada informasi $3 / 2$ kali.

Subjek 1: Oh, berarti tetap luas $A$ itu sama dengan $3 / 2$ nya luas $B$ ya, $\mathrm{Bu}$ ? Seperti ini (menuliskan yang dimaksud)

Peneliti : Iya, benar. Itu tetap 3/2 kalinya, buka 3:2. Sekarang coba kamu buat gambar dari bangun $B$ !
Subjek 1: Begini (menggambar persegi panjang)

Peneliti : Tadi yang sudah diketahui panjang dan panjang diagonal bangun $B$, itu yang mana?

Subjek 1: (menunjukkan panjang dan diagonal bangun $B$ )

Peneliti : Berarti sisi yang lain ini apa? (menunjuk pada sisi yang dimaksud)

Subjek 1: Berarti ini lebarnya.

Setelah pemberian scaffolding, S1 dapat memahami cara penulisan model matematika dari informasi yang diketahui dengan benar. S1 dapat melanjutkan langkah-langkah penyelesai-an sehingga memperoleh hasil jawaban yang benar.

Dalam menyelesaikan masalah nomor 2, S2 dapat membuat sketsa dari yang diketahui namun dia mengalami kesalahan memahami soal seperti halnya S1. Selain itu, S2 tidak dapat mengaitkan permasalahan dengan materi yang diperlukan disini yaitu teorema Pythagoras, sehingga S2 tidak dapat melanjutkan langkah penyelesaian masalah.

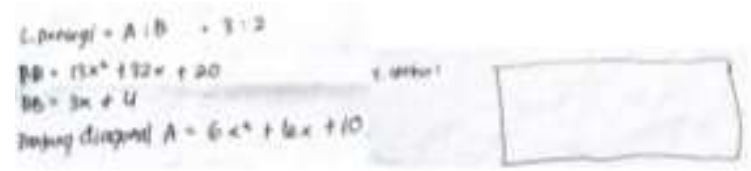

Gambar 4 Jawaban S2 dalam Menyelesaikan Masalah Nomor 2

Berikut scaffolding yang diberikan peneliti kepada S2 sehingga S2 tidak mengalami kesalahan karena tidak dapat mengaitkan dengan teorema Pythagoras. 
Peneliti : Untuk mencari panjang diagonal ini bagaimana?

Subjek 2: Setengah dari luas?

Peneliti : Cara yang lain bagaimana? DB kan yang ini (menunjuk yang dimaksud), cara mencarinya bagaimana?

Subjek 2: Oh, mencari sisi miring

Peneliti : Bagaimana?

Subjek 2: Ini kuadrat ditambah ini kuadrat (menunjuk panjang dan lebar bangun B)

Peneliti : Berarti pakai teorema apa?

Subjek 2: Teorema Pythagoras

Peneliti : Iya. Ini tadi apa? (menunjuk yang dimaksud)

Subjek 2: $D B$

Peneliti : Kalau yang ini? (menunjuk yang dimaksud) sambil ditulis

Subjek 2: Lebar dan panjangnya

Peneliti : Berarti mencari DB bagaimana? $D B) 2$ sama dengan?

Subjek2 : $D B^{\wedge} 2=l B^{\wedge} 2+p B^{\wedge} 2$

Dengan pemberian scaffolding ini, S2 dapat mengingat dan memanfaatkan teorema Pythagoras dalam menyelesai-kan masalah sehingga dapat menyelesai-kan dengan mudah dan tepat.

\section{Penutup}

\section{Simpulan}

Dari hasil penelitian dan pembahasan yang telah diuraikan, dapat disimpulkan bahwa dengan pemberian scaffolding untuk mengatasi kesalahan siswa dalam menyelesaikan masalah matematika yaitu sebagai berikut.
1) Scaffolding dalam penyusunan model matematika dalam bentuk aljabar;

2) Scaffolding dalam membangun kembali konsep bangun datar, khususnya luas dan keliling persegi dan persegi panjang;

3) Scaffolding dalam menyelesaikan operasi bentuk aljabar; dan

4) Scaffolding dalam memanfaatkan teorema Pythagoras dalam menyelesaikan masalah matematika.

\section{Saran}

Dari hasil penelitian ini, peneliti menyampaikan beberapa saran sebagai berikut.

1) Peneliti selanjutnya dapat memberikan scaffolding serta skema berpikir siswa dalam menyelesaikan masalah matematika.

2) Pendidik dapat menganalisis kesalah-an siswa sehingga dapat memberikan scaffolding yang sesuai menghindari kesalahan yang terjadi ketika siswa menyelesaikan masalah matematika.

3) Pendidik tidak hanya memberikan scaffolding semata-mata kepada siswa tetapi siswa harus dapat memahami apa yang dimaksud, ditanyakan, dan rencana penyelesaian yang tepat dalam menyelesaikan masalah matematika.

\section{Daftar Rujukan}

Anghileri, Julia. 2006. Scaffolding Practice That Enchance 
Mathematics Learning. Journal of Mathematics Teacher Education, 9. 33-52.

Arikunto, Suharsimi. 2010. Prosedur Penelitian Suatu Pendekatan Praktik. Yogyakarta: PT Rineka Cipta

Bikmaz, Fatma H, dkk. 2010. Scaffolding Strategies Applied by Student Teachers to Teach Mathematics. The International Journal of Research in Teacher Education 2010, 1(Special Issue): 25-36 ISSN: 1308-951X Crespo, S. \& Nicol, C. (2003). Learning To Investigate Students' Mathematical Thinking: The Role Of Student Interviews. In N. A. Pateman, B. Dougherty, \& J. T. Zilliox (Eds). Proceeding of the International Group for the Psychology of Mathematics Education, 27, (vol. 2) (pp. 261268)

Creswell, John W. 2012. Education Research: Planning, Conducting, and Evaluating Quantitative and Qualitative Reasearch. Boston: Pearson

Hanifah, Ayu Ismi. 2016. Analisis Kesalahan Siswa dilihat dari Skema dalam Menyelesaikan Masalah Matematika. UNISLA: FKIP

Howe, Christine. 2013. Scaffolding in context: Peer interaction and abstract learning. Journal: Learning, Culture, and Social Interaction 2 (2013) 3-10, www.elsevier.com
NCTM. 2000. Principles and Standart for School Mathematics. US: National Council of Teachers of Mathematics

Pol, Janneke Van de, Ed Elbers. 2013. Scaffolding Student Learning: A Micro-Analysis of TeacherStudent Interaction. Journal: Learning, Culture, and Social Interaction 2 (2013) 32-41, www.elsevier.com

Trianto. 2010. Mendesain Model Pembelajaran Inovatif Progresif. Jakarta: Kencana 
